\title{
High Body Mass Has No Effect on Cellular and Innate Immunity in Siberian Hamsters (Phodopus sungorus)
}

\author{
Yufen Tian1, Mengmeng Chen², Xiangdi Cui², Min Du², Qiuli Yu², Xiaokai Hu², Deli Xu² \\ ${ }^{1}$ Library, Qufu Normal University, Qufu, China; ${ }^{2}$ College of Life Sciences, Qufu Normal University, Qufu, China \\ Correspondence to: Deli Xu, xudl1975@163.com
}

Keywords: Phytohaemagglutinin Response, Bacteria Killing Capacity, Body Fat, Glucose, Siberian Hamsters

(Phodopus sungorus)

Received: June 5, $2017 \quad$ Accepted: July 22, $2017 \quad$ Published: July 25, 2017

Copyright () 2017 by authors and Scientific Research Publishing Inc.

This work is licensed under the Creative Commons Attribution International License (CC BY 4.0).

http://creativecommons.org/licenses/by/4.0/

\section{(c) () Open Access}

\section{ABSTRACT}

Body mass is considered to be related with immune function in animals. Our aim was to test the hypothesis that cellular and innate immunity would be suppressed in high body mass of Siberian hamsters (Phodopus sungorus). Six heavier (high body mass, HBM) and six lighter (low body mass, LBM) hamsters were selected from 28 male hamsters. Body mass, body fat mass, wet spleen mass and blood glucose levels were significantly higher in the HBM group than in the LBM group. However, phytohaemagglutinin response, serum bacteria killing capacity and white blood cells did not differ between the two groups, suggesting cellular and innate immunity was not impaired in high body mass of hamsters. There was no correlation between cellular, innate immunity and body mass, body fat mass and glucose levels, suggesting cellular and innate immunity was not suppressed by higher body mass, body fat mass and glucose levels. In summary, cellular and innate immunity was not impaired in the HBM hamsters compared with the LBM hamsters.

\section{INTRODUCTION}

Obesity becomes more and more prevalent and it is associated with several chronic diseases [1-5]. It is also considered to be related with increased susceptibility to infections $[6,7]$. The mechanism may be due to the changes of immune responses in obesity [8-10].

Effect of obesity on immune function has been carried out in some obese animals [11]. Cellular immunity is suppressed in $o b / o b$ mice whose leptin gene was genetically mutated [12-14]. It is also impaired in $d b / d b$ mice and fal fa rats whose mutation in leptin receptor gene $[15,16]$. Suppression of immune responses are also observed in diet-induced obese mice [17-19] or rats [20,21]. Both cellular and humoral immunity are dampened in overweight Mongolian gerbils (Meriones unguiculatus) [22]. Likewise, obese human also show decrease in the capacity of lymphocyte proliferation [23] and humoral immunity [24, 25]. However, immune responses were not changed in diet-induced obese cats [26]. 
Serum bacterial killing capacity is usually examined to assess innate immunity, which is one arm of immune system [27-29]. This assay was performed in a sterile laminar flow cabinet to assess the functional response by the animal's innate immune system against a relevant pathogen (i.e., Escherichia coli) [27-29]. Cellular immunity belongs to adaptive immune system which is responsible for controlling intracellular pathogens [9]. It is often evaluated by phytohaemagglutinin (PHA) response, which involves a subcutaneous injection of PHA that induces local T-cell stimulation and proliferation resulting in swelling [30, 31]. Immune organs including thymus and spleen are indirect immunological parameters [32, 33]. In addition, white blood cells (WBC) are also used to assess the overall health [34], and the increase of WBC is related with inflammation in obesity $[3,35]$.

Adipose tissues are not only energy reserves, but also are considered as important endocrine and immune organs [36-39]. Glucose plays a role in normal survival and function of lymphocytes, and glucose uptake and glycolysis increase in T cells during an immune response [40,41], whereas hyperglycemia reduces immune function $[42,43]$.

The major problem in understanding the influence of overweight or obesity on immunity in human is that the obese population is too heterogeneous in various aspects, including dietary patterns, individual microbial and social environments [10]. Furthermore, the percentage of obesity caused by genetic deficiency is small [11]. Therefore, wild overweight or obese rodents perhaps are potential model to examine the impact of obesity on immunity independently of the confounding heterogeneity in human [10]. To date, however, little information is available about how obesity or overweight affects immune function in wild rodents.

Siberian hamsters (Phodopus sungorus) are small seasonal breeding and granivorous rodents mainly living in the desert and semi-arid regions of Mongolia in China [44, 45]. Previous work has demonstrated this species undergoes changes in immunity $[46,47]$ and decreases in body mass and fat mass in response to "winter-like" conditions $[48,49]$. Reduction in fat mass harms humoral immunity in striped hamsters [50], implying that immunity may be related with body mass. In the present study, we are to test the hypothesis that innate and cellular immunity will be impaired in high body mass of Siberian hamsters.

\section{MATERIALS AND METHODS}

\subsection{Animals and Experimental Design}

All animal procedures were licensed under the Animal Care and Use Committee of Qu Normal University. Adult male Siberian hamsters used in this study were the offspring of hamsters in our laboratory colony. The hamsters were housed individually after weaning in plastic cages $(30 \mathrm{~cm} \times 15 \mathrm{~cm} \times 20 \mathrm{~cm})$ with sawdust as bedding under a constant photoperiod of $12 \mathrm{~L}: 12 \mathrm{D}$ (12 h:12 h light-dark cycle) and temperature of $23^{\circ} \mathrm{C} \pm 1^{\circ} \mathrm{C}$. Commercial standard rat pellets (Beijing KeAo Feed Co.) and water was provided at ad libitum throughout the experiment. The macronutrients of the diet were $6.2 \%$ crude fat, $18 \%$ crude protein, $23.1 \%$ neutral fiber, $5 \%$ crude fiber, $12.5 \%$ acid detergent fiber, and $10.0 \%$ ash, and the caloric value was $17.5 \mathrm{~kJ} / \mathrm{g}$. After body mass stabilized, we selected 6 heavier (21.4\%) (high body mass, HBM) and 6 lighter (21.4\%) (low body mass, LBM) hamsters from 28 males (age: 10 to 12 months).

\subsection{Organs}

Visceral organs were dissected as described previously [31]. In brief, after interscapular BAT (IBAT) was removed, the visceral organs, including heart, thymus, lungs, liver, spleen, kidneys, testes, epididymis, seminal vesicals and the digestive organs with contents (i.e., stomach, small intestine, caecum and colon) were dissected and weighed $( \pm 1 \mathrm{mg})$. The stomach, small intestine, caecum and colon were rinsed with saline to eliminate all the gut contents, before being weighed.

\subsection{Body Composition}

Perigonadal fat, mesenteric fat, retroperitoneal fat and subcutaneous fat were also dissected carefully and weighted. The mass of the four fat pads is considered as total body fat, and the fat content was calculated 
as perigonadal fat, mesenteric fat, retroperitoneal fat, subcutaneous fat and total fat mass divided by wet carcass mass [51].

\subsection{Cellular Immunity Assays}

PHA response (i.e., cellular immunity) was measured as described previously [30, 31]. Briefly, we measured the footpad thickness of their left hind feet with a micrometer (Tesa Shopcal, Swiss) to \pm 0.01 $\mathrm{mm}$. Immediately thereafter, hamsters were injected subcutaneously $0.1 \mathrm{mg}$ of PHA dissolved in $0.03 \mathrm{ml}$ sterile saline in the middle of the footpad. After $6 \mathrm{~h}, 12 \mathrm{~h}, 24 \mathrm{~h}, 48 \mathrm{~h}$ injection, we measured footpad thicknes. The PHA response was calculated as the difference between pre- and post-injection measurements divided by initial footpad thickness $(\mathrm{PHA}$ response $=($ post PHA - pre PHA)/pre PHA). Each measurement of PHA response was replicated six times on the same hamster [30, 31]. Only PHA responses after $6 \mathrm{~h}$ of PHA injection were included in the results because they were representative of the maximal response.

\subsection{White Blood Cells Assays}

At the end of the experiment, after collecting trunk blood, $20 \mu$ whole blood was diluted immediately in $0.38 \mathrm{ml}$ solution containing $1.5 \%$ glacial acetic acid, $1 \%$ crystal violet (Sigma) and the leukocytes were counted in an improved Neubauer chamber using microscope. The total number of WBC was determined by counting all leucocytes in the four corner large-squares of the Neubauer chamber, and multiplying the raw data by $5 \times 10^{7}$ to obtain the final values $\left(10^{9}\right.$ cells $\left./ 1\right)[52]$.

\subsection{Innate Immunity}

Serum bacterial killing capacity indicative of innate immunity was performed in a sterile laminar flow cabinet to assess the functional response by the animal's innate immune system against a relevant pathogen, Escherichia coli [27-29]. Briefly, serum samples were diluted 1:20 in $\mathrm{CO}_{2}$-independent medium (Gibco no. 18,045, Carlsbad, GA, USA). A standard number of colony-forming units (CFUs) of E. coli (ATCC no. 8739, Microbial Culture Collection Center of Guangdong Institute of Microbiology, China) was added to each sample in a ratio of 1:10, and the mixture (i.e., a number of E. coli dissolved in $\mathrm{CO}_{2}$-independent medium, serum samples and $\mathrm{CO}_{2}$-independent medium) was allowed to incubate at $37^{\circ} \mathrm{C}$ for 30 min to induce bacterial killing. After incubation, $50 \mu \mathrm{l}$ of each sample was added to tryptic soy agar plates in duplicate. All plates were covered and left to incubate upside down at $37^{\circ} \mathrm{C}$ for $24 \mathrm{~h}$, and then total CFUs were counted and bactericidal capacity was calculated as $100 \%$ minus the mean number of CFUs for each sample divided by the mean number of CFUs for the positive controls (containing only medium and standard bacterial solution), i.e. the percentage of bacteria killed relative to the positive control.

\subsection{Blood Glucose Assays}

Blood glucose levels were measured with FreeStyle Mini Blood Meter (Abbott Diabetes Care Inc. Alameda, USA) according to the manufacture's instructions. The range tested of blood glucose was 1.1 $27.8 \mathrm{mmol} / \mathrm{l}$. The within-lot and -vial variabilities were $<5.6 \%$ and $<4.1 \%$, respectively [31].

\subsection{Statistical Analysis}

Data were analyzed using SPSS 13.0 software (SPSS Inc., Chicago, IL, USA). Prior to all statistical analyses, data were examined for normality and homogeneity of variance, using Kolmogorov-Smirnov and Levene tests, respectively. The ratio values including PHA response were subjected to arcsine transformation. The differences of body mass between the control and experimental groups at any time point were analyzed by independent-samples t-test. Group differences in wet organ mass with body mass as the covariate were analyzed by General Linear Model multivariate analysis followed by Bonferroni post hoc tests. Group differences in other parameters (body compositions, PHA response, WBC) were analyzed by 
independent-samples t-test. Results were expressed as mean $\pm \mathrm{SE}$, and $P<0.05$ was considered to be statistically significant.

\section{RESULTS}

\subsection{Body Composition}

The HBM hamsters had significantly higher body mass, wet carcass mass, perigonadal, mesenteric and total body fat mass than those of the LBM hamsters, while retroperitoneal and subcutaneous fat mass did not differ between the two groups (Table 1).

\subsection{Organs}

Masses of lung, spleen, kidneys, stomach, colon with contents, colon, total digestive tract and the length of small intestine, colon, total digestive tract in the HBM group were higher than those of the LBM group (Table 2). Other organ masses including heart, thymus, liver, small intestine, caecum, testes, epididymis and seminal vesical were not different between the two groups (Table 2).

\subsection{White Blood Cells}

There was no significant difference of WBC between the HBM and LBM groups $(t=-1.105, \mathrm{df}=10$, $P=0.295)$ (Figure 1).

\subsection{Cellular Immune Response}

No significant difference of PHA response between the HBM and LBM groups was observed $(\mathrm{t}=$

Table 1. Body composition in the high and low body mass of Siberian hamsters.

\begin{tabular}{ccccc}
\hline \multirow{2}{*}{ Parameters } & \multicolumn{2}{c}{ Groups } & \multicolumn{2}{c}{ Statistical summary } \\
\cline { 2 - 5 } & HBM & LBM & $\mathrm{t}$ & $P$ \\
\hline Initial body mass (g) & $50.8 \pm 0.8^{\mathrm{a}}$ & $29.2 \pm 0.8^{\mathrm{b}}$ & 19.025 & $<0.001$ \\
Final body mass (g) & $51.2 \pm 3.7^{\mathrm{a}}$ & $31.1 \pm 1.2^{\mathrm{b}}$ & 5.167 & $<0.001$ \\
Wet carcass mass (g) & $36.7 \pm 7.1^{\mathrm{a}}$ & $22.6 \pm 2.6^{\mathrm{b}}$ & 4.550 & 0.001 \\
Perigonadal fat (g) & $1.273 \pm 0.356^{\mathrm{a}}$ & $0.343 \pm 0.141^{\mathrm{b}}$ & 5.951 & $<0.001$ \\
Mesenteric fat (g) & $0.546 \pm 0.169^{\mathrm{a}}$ & $0.284 \pm 0.067^{\mathrm{b}}$ & 3.522 & 0.006 \\
Retroperitoneal fat (g) & $0.231 \pm 0.167$ & $0.080 \pm 0.053$ & 2.106 & 0.061 \\
Subcutaneus fat (g) & $1.538 \pm 1.556^{\mathrm{a}}$ & $0.823 \pm 0.217^{\mathrm{b}}$ & 1.116 & 0.291 \\
Total body fat (g) & $3.588 \pm 2.034^{\mathrm{a}}$ & $1.530 \pm 0.450^{\mathrm{b}}$ & 2.420 & 0.036 \\
Perigonadal fat content (\%) & $0.031 \pm 0.006$ & $0.014 \pm 0.005$ & 5.141 & $<0.001$ \\
Mesenteric fat content (\%) & $0.013 \pm 0.002$ & $0.012 \pm 0.003$ & 1.132 & 0.284 \\
Retroperitoneal fat content (\%) & $0.005 \pm 0.003$ & $0.003 \pm 0.002$ & 1.089 & 0.302 \\
Subcutaneus fat content (\%) & $0.034 \pm 0.033^{\mathrm{a}}$ & $0.033 \pm 0.008^{\mathrm{b}}$ & 0.090 & 0.930 \\
Total body fat content (\%) & $0.084 \pm 0.039^{\mathrm{a}}$ & $0.062 \pm 0.017^{\mathrm{b}}$ & 1.270 & 0.233 \\
\hline
\end{tabular}

Values are means $\pm S E(n=6)$. Values for a specific parameter that shares different superscripts are significantly different at $P<0.05$, determined by independent $\mathrm{t}$-test analysis. HBM: high body mass; LBM: low body mass. 
Table 2. Wet organ mass in the high and low body mass of Siberian hamsters.

\begin{tabular}{|c|c|c|c|c|}
\hline \multirow{2}{*}{ Parameters } & \multicolumn{2}{|c|}{ Groups } & \multicolumn{2}{|c|}{ Statistical summary } \\
\hline & HBM & LBM & $\mathrm{F}$ & $P$ \\
\hline Heart (g) & $0.294 \pm 0.494$ & $0.204 \pm 0.027$ & 0.938 & 0.358 \\
\hline Lungs (g) & $0.338 \pm 0.020^{\mathrm{a}}$ & $0.282 \pm 0.057^{\mathrm{b}}$ & 7.916 & 0.020 \\
\hline Thymus (g) & $0.014 \pm 0.008^{\mathrm{b}}$ & $0.014 \pm 0.006^{\mathrm{a}}$ & 7.712 & 0.022 \\
\hline Liver (g) & $2.282 \pm 0.624$ & $1.319 \pm 0.191$ & 1.168 & 0.308 \\
\hline Spleen $(g)$ & $0.219 \pm 0.041^{\mathrm{a}}$ & $0.139 \pm 0.047^{\mathrm{b}}$ & 14.296 & 0.004 \\
\hline Kidneys (g) & $0.807 \pm 0.157^{\mathrm{a}}$ & $0.386 \pm 0.068^{\mathrm{b}}$ & 10.727 & 0.010 \\
\hline Stomach with contents (g) & $1.493 \pm 0.331$ & $0.991 \pm 0.186$ & 1.584 & 0.240 \\
\hline Stomach $(\mathrm{g})$ & $0.377 \pm 0.060^{\mathrm{a}}$ & $0.234 \pm 0.084^{\mathrm{b}}$ & 12.237 & 0.007 \\
\hline Small intestine with contents (g) & $2.030 \pm 0.187^{\mathrm{a}}$ & $1.288 \pm 0.142^{\mathrm{b}}$ & 1.378 & 0.271 \\
\hline Small intestine (g) & $0.539 \pm 0.144$ & $0.481 \pm 0.105$ & 0.734 & 0.414 \\
\hline Small intestine length $(\mathrm{cm})$ & $30.9 \pm 2.5^{\mathrm{a}}$ & $27.2 \pm 1.5^{\mathrm{b}}$ & 40.454 & 0.000 \\
\hline Caecum with contents (g) & $1.092 \pm 0.328$ & $0.854 \pm 0.131$ & 0.770 & 0.403 \\
\hline Caecum $(g)$ & $0.191 \pm 0.068$ & $0.198 \pm 0.063$ & 2.826 & 0.127 \\
\hline Caecum length $(\mathrm{cm})$ & $4.9 \pm 0.9$ & $5.1 \pm 1.9$ & 0.073 & 0.793 \\
\hline Colon with contents (g) & $1.011 \pm 0.290^{\mathrm{a}}$ & $0.603 \pm 0.169^{\mathrm{b}}$ & 22.176 & 0.001 \\
\hline Colon $(\mathrm{g})$ & $0.372 \pm 0.134^{\mathrm{a}}$ & $0.209 \pm 0.054^{\mathrm{b}}$ & 13.095 & 0.006 \\
\hline Colon length $(\mathrm{cm})$ & $16.9 \pm 1.6^{\mathrm{a}}$ & $12.5 \pm 1.4^{\mathrm{b}}$ & 48.204 & $<0.001$ \\
\hline Total digestive tract $(\mathrm{g})$ & $1.102 \pm 0.222^{\mathrm{a}}$ & $0.887 \pm 0.157^{\mathrm{b}}$ & 7.317 & 0.024 \\
\hline Total digestive tract length $(\mathrm{cm})$ & $52.7 \pm 1.9^{\mathrm{a}}$ & $44.7 \pm 3.1^{\mathrm{b}}$ & 77.836 & $<0.001$ \\
\hline Testes (g) & $0.654 \pm 0.138$ & $0.164 \pm 0.118$ & 4.215 & 0.070 \\
\hline Epididymis (g) & $0.088 \pm 0.032$ & $0.035 \pm 0.019$ & 2.841 & 0.126 \\
\hline Seminal vesical (g) & $0.654 \pm 0.232$ & $0.058 \pm 0.061$ & 3.619 & 0.090 \\
\hline
\end{tabular}

Values are means $\pm S E(n=6)$. Values for a specific parameter that shares different superscripts are significantly different at $P<0.05$, determined by a multivariate analysis with body mass as the covariate. HBM: high body mass; LBM: low body mass.

1.272 , $\mathrm{df}=10, P=0.232)$ (Figure 2). PHA response was not correlated with body mass $(\mathrm{r}=0.140, P=$ $0.665)$ and total body fat mass $(\mathrm{r}=0.069, P=0.831)$.

\subsection{Innate Immunity}

Bacteria killing capacity indicative of innate immunity did not differ between the HBM and LBM groups $(\mathrm{t}=-1.167, \mathrm{df}=10, P=0.271)$ (Figure 3 ). No correlation was observed between innate immunity and body mass $(\mathrm{r}=0.396, P=0.202)$, total body fat mass $(\mathrm{r}=0.118, P=0.716)$.

\subsection{Blood Glucose Levels}

The HBM hamsters had higher blood glucose levels than those of the LBM hamsters $(\mathrm{t}=3.672, \mathrm{df}=$ $10, P<0.05)$ (Figure 4). Blood glucose levels were not correlated with cellular $(\mathrm{r}=0.337, P=0.283)$ and 


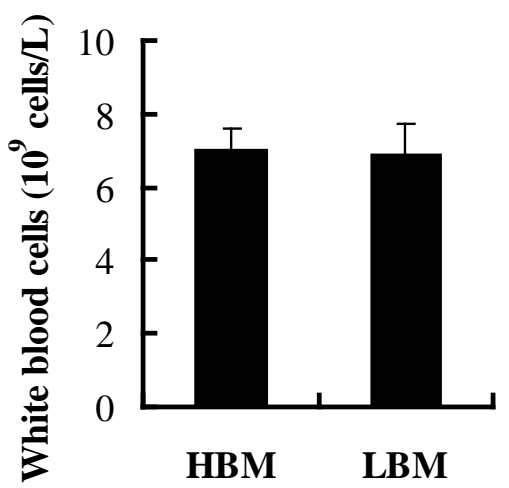

Figure 1. White blood cells in the high and low body mass of Siberian hamsters.

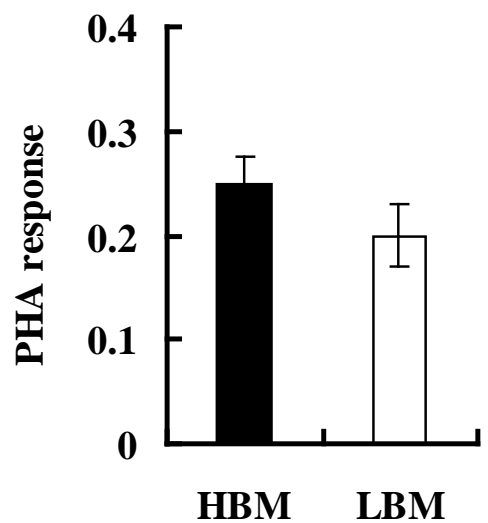

Figure 2. PHA response in the high and low body mass of Siberian hamsters.

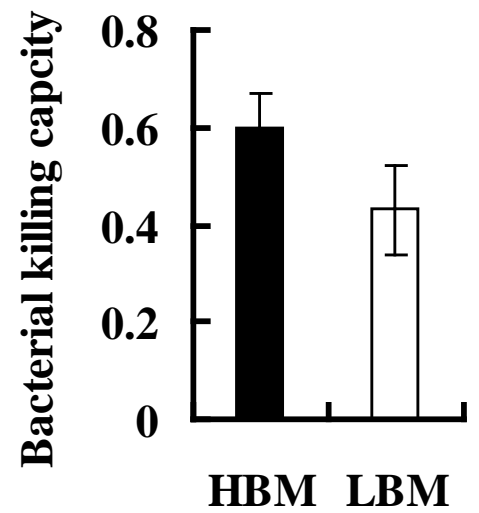

Figure 3. Innate immunity in the high and low body mass of Siberian hamsters.

innate immunity, but positively correlated with body mass and total body fat mass $(\mathrm{r}=0.750, P=0.005)$ $(\mathrm{r}=0.855, P<0.001)$.

\section{DISCUSSION}

Our main results showed that PHA response, serum bacteria killing capacity and white blood cells did 


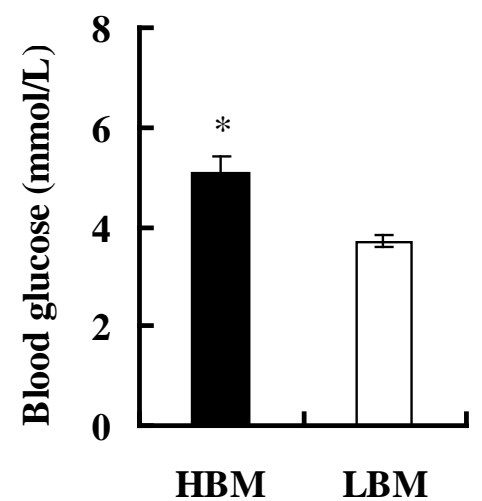

Figure 4. Blood glucose levels in the high and low body mass of Siberian hamsters.

not differ between the high and low body mass groups, indicating that both cellular and innate immunity were not suppressed in the high body mass hamsters. This result did not agree with our previous study in which cellular and humoral immunity were impaired in overweight Mongolian gerbils [22]. Higher body mass, body fat mass, and blood glucose levels might not explain these results. Spleen mass was higher in HBM hamsters than LBM hamsters, while thymus mass was not different between the two groups. This finding was inconsistent with other research in which both thymus and spleen mass were reduced in $o b / o b$ mice [53].

Cellular or humoral immunity may be suppressed due to excessive body mass or fat loss during starvation $[31,54,55]$ or experimental reductions in body fat [50]. Similarly, immune function can be impaired owning to excessive body mass or fat gain such as in obesity $[6,10,56]$. In the present experiment, we found that high body mass did not influence cellular and innate immunity in hamsters. Additionally, PHA response and innate immunity were not correlated with body mass and body fat mass in hamsters, indicating cellular and innate immunity were not influenced by higher body mass and body fat mass in hamsters. The small sample size in our study might be also responsible for these results.

Glucose provides energy for immune responses [40, 41]. However, hyperglycemia may harm immunity through non-enzymatic glycosylation of circulating immunoglobulins [42, 43]. In our study, no significant correlation was observed between glucose levels and cellular, innate immunity, suggesting higher levels of glucose in the HBM hamsters had no effect on immune function in contrast with the LBM hamsters. Blood glucose levels were positively correlated with body mass and body fat mass, indicating that higher body mass and body fat mass contributed to hyperglycemia in the HBM hamsters.

In summary, body mass, body fat mass and blood glucose levels were higher in the HBM hamsters than in the LBM hamsters. Both cellular and innate immunities were not affected by body mass in hamsters, indicating healthy immune function in high body mass hamsters.

\section{ACKNOWLEDGEMENTS}

We are grateful for the support of the National Natural Science Foundation of China (31370427) to DLX.

\section{REFERENCES}

1. Conway, B. and Rene, A. (2004) Obesity as a Disease: No Lightweight Matter. Obesity Reviews, 5, $145-151$. https://doi.org/10.1111/j.1467-789X.2004.00144.x

2. Lazar, M.A. (2005) How Obesity Causes Diabetes: Not a Tall Tale. Science, 307, 373-375.

https://doi.org/10.1126/science.1104342 
3. Hotamisligil, G.S. (2006) Inflammation and Metabolic Disorders. Nature, 444, 860-867. https://doi.org/10.1038/nature05485

4. Irigaray, P., Newby, J.A., Lacomme, S. and Belpomme, D. (2007) Overweight/Obesity and Cancer Genesis: More than a Biological Link. Biomedicine Pharmacotherapy, 61, 665-678. https://doi.org/10.1016/j.biopha.2007.10.008

5. Speakman, J., Hambly, C., Mitchell, S. and Król, E. (2008) The Contribution of Animal Models to the Study of Obesity. Laboratory Animal, 42, 413-432. https://doi.org/10.1258/la.2007.006067

6. Samartín, S. and Chandra, R.K. (2001) Obesity, Overnutrition and the Immune System. Nutrition Research, 21, 243-262. https://doi.org/10.1016/S0271-5317(00)00255-4

7. Falagas, M.E. and Kompoti, M. (2006) Obesity and Infection. Lancet Infectious Diseases, 6, 438-446. https://doi.org/10.1016/S1473-3099(06)70523-0

8. Kumari, B.S. and Chandra, R.K. (1993) Overnutrition and Immune Responses. Nutrition Research, 13, S3-S18. https://doi.org/10.1016/S0271-5317(05)80281-7

9. Marti, A., Marcos, A. and Martinez, J.A. (2001) Obesity and Immune Function Relationships. Obesity Reviews, 2, 131-140. https://doi.org/10.1046/j.1467-789x.2001.00025.x

10. Lamas, O., Marti, A. and Martínez, J.A. (2002) Obesity and Immunocompetence. European Journal of Clinical Nutriton, 56, S42-S45. https://doi.org/10.1038/sj.ejcn.1601484

11. Matarese, G. and Cava, A.L. (2005) Immune Responses in Obesity Models. Drug Discovery Today. Diseases Model, 2, 177-181.

12. Chandra, R.K. (1980) Cell-Mediated Immunity in Genetically Obese C57BL/6J ob/ob Mice. American Journal of Clinical Nutrition, 33, 13-16.

13. Busso, N., So, A., Chobaz-Péclat, V., Morard, C., Martinez-Soria, E., Talabot-Ayer, D. and Gabay, C. (2002) Leptin Signaling Deficiency Impairs Humoral and Cellular Immune Responses and Attenuates Experimental Arthritis. Journal of Immunology, 168, 875-882. https://doi.org/10.4049/jimmunol.168.2.875

14. Lindström, P. (2007) The Physiology of Obese-Hyperglycemic Mice [ob/ob Mice]. The Scientific World Journal, 7, 666-685. https://doi.org/10.1100/tsw.2007.117

15. Mandel, M.A. and Mahmoud, A.A.F. (1978) Impairment of Cell Mediated Immunity in Mutation Diabetic Mice $(\mathrm{db} / \mathrm{db})$. Journal of Immunology, 120, 1375-1377.

16. Tanaka, S., Isoda, F., Kiuchi, Y., Ikeda, H., Mobbs, C.V. and Yamakawa, T. (2000) T Lymphopenia in Genetically Obese-Diabetic Wistar Fatty Rats: Effects of Body Weight Reduction on T Cells. Metabolism, 49, 1261-1266. https://doi.org/10.1053/meta.2000.9516

17. Mito, N., Kitada, C., Hosoda, T. and Sato, K. (2002) Effect of Diet-Induced Obesity on Ovalbumin-Specific Immune Response in a Murine Asthma Model. Metabolism, 51, 1241-1246. https://doi.org/10.1053/meta.2002.35196

18. Amar, S., Zhou, Q., Shaik-Dasthagirisaheb, Y. and Leeman, S. (2007) Diet-Induced Obesity in Mice Causes Changes in Immune Responses and Bone Loss Manifested by Bacterial Challenge. Proceedings of the National Academy of Sciences, 104, 20466-20471. https://doi.org/10.1073/pnas.0710335105

19. Smith, A.G., Sheridan, P.A., Harp, J.B. and Beck, M.A. (2007) Diet-Induced Obese Mice Have Increased Mortality and Altered Immune Responses When Infected with Influenza Virus. Journal of Nutrition, 137, 1236-1243.

20. Moriguchi, S., Kato, M., Sakai, K., Yamamoto, S. and Shimizu, E. (1998) Exercise Training Restores Decreased Cellular Immune Functions in Obese Zucker Rats. Journal of Applied Physiology, 84, 311-317.

21. Lamas, O., Martínez, J.A. and Marti, A. (2004) Energy Restriction Restores the Impaired Immune Response in Overweight (Cafeteria) Rats. Journal of Nutritional Biochemistry, 15, 418-425. 
22. Xu, D.L., Liu, X.Y. and Wang, D.H. (2011) Impairment of Cellular and Humoral Immunity in Overweight Mongolian Gerbils (Meriones unguiculatus). Integrative Zoology, 6, 353-366.

23. Nieman, D.C., Henson, D.A., Nehlsen-Cannarella, S.L., Ekkens, M., Utter, A.C., Butterworth, D.E. and Fagoaga, O.R. (1999) Influence of Obesity on Immune Function. Journal of American Dietetic Association, 99, 294-299.

24. Weber, D.J., Rutala, W.A., Samsa, G.P., Bradshaw, S.E. and Lemon, S.M. (1986) Impaired Immunogenicity of Hepatitis B Vaccine in Obese Persons. The Journal of American Medical Association, 254, 3187-3189. https://doi.org/10.1001/jama.1985.03360220053027

25. Eliakim, A., Swindt, C., Zaldivar, F., Casali, P. and Cooper, D.M. (2006) Reduced Tetanus Antibody Titers in Overweight Children. Autoimmunity, 39, 137-141. https://doi.org/10.1080/08916930600597326

26. Jaso-Friedmann, L., Leary, J.H., Praveen, K., Waldron, M. and Hoenig, M. (2008) The Effects of Obesity and Fatty Acids on the Feline Immune System. Veterinary Immunology and Immunopathology, 122, 146-152.

27. Tieleman, B.I., Williams, J.B., Ricklefs, R.E. and Klasing, K.C. (2005) Constitutive Innate Immunity Is a Component of the Pace-of-Life Syndrome in Tropical Birds. Proceedings of the Royal Society B, 272, 1715-1720. https://doi.org/10.1098/rspb.2005.3155

28. Demas, G.E., Zysling, D.A., Beechler, B.R., Muehlenbein, M.P. and French, S.S. (2011) Beyond Phytohaemagglutinin: Assessing Vertebrate Immune Function across Ecological Contexts. Journal of Animal Ecology, 80, 710-730. https://doi.org/10.1111/j.1365-2656.2011.01813.x

29. Yang, D.B., Xu, Y.C., Wang, D.H. and Speakman, J.R. (2013) Effects of Reproduction on Immuno-Suppression and Oxidative Damage, and Hence Support or Otherwise for Their Roles as Mechanisms Underpinning Life History Tradeoffs, Are Tissue and Assay Dependent. Journal of Experimental Biology, 216, 4242-4250. https://doi.org/10.1242/jeb.092049

30. Bellocq, J.G., Krasnov, B.R., Khokhlova, I.S. and Pinshow, B. (2006) Temporal Dynamics of a T-Cell Mediated Immune Response in Desert Rodents. Comparative and Biochemical Physiology A, 145, 554-559.

31. Xu, D.L. and Wang, D.H. (2010) Fasting Suppresses T Cell-Mediated Immunity in Female Siberian Hamsters (Meriones unguiculatus). Comparative and Biochemical Physiology A, 155, 25-33.

32. Savino, W. and Dardenne, M. (2000) Neuroendocrine Control of Thymus Physiology. Endocrine Reviews, 21, 412-443. https://doi.org/10.1210/er.21.4.412

33. Smith, K.G. and Hunt, J.L. (2004) On the Use of Spleen Mass as a Measure of Avian Immune System Strength. Oecologia, 138, 28-31. https://doi.org/10.1007/s00442-003-1409-y

34. Calder, P.C. and Kew, S. (2002) The Immune System: A Target for Functional Foods? British Journal of Nutrition, 88, S165-S176. https://doi.org/10.1079/BJN2002682

35. Dixon, J.B. and O'Brien, P.E. (2006) Obesity and the White Blood Cell Count: Changes with Sustained Weight Loss. Obesity Surgery, 16, 251-257. https://doi.org/10.1381/096089206776116453

36. Ahima, R.S. and Flier, J.S. (2000) Adipose Tissue as an Endocrine Organ. Trends in Endocrinology and Metabolism, 11, 327-332.

37. Fantuzzi, G. (2005) Adipose Tissue, Adipokines, and Inflammation. Journal of Allergy Clinical Immunology, 115, 911-919.

38. McGillis, J.P. (2005) White Adipose Tissue, Inert No More! Endocrinology, 146, 2154-2156. https://doi.org/10.1210/en.2005-0248

39. Schäffler, A., Schölmerich, J. and Salzberger, B. (2007) Adipose Tissue as an Immunological Organ: Toll-Like Receptors, C1q/TNFs and CTRPs. Trends in Immunology, 28, 393-399.

40. Matarese, G. and Cava, A.L. (2004) The Intricate Interface between Immune System and Metabolism. Trends in Immunology, 5, 193-200. 
41. Maciver, N.J., Jacobs, S.R., Wieman, H.L., Wofford, J.A., Coloff, J.L. and Rathmell, J.C. (2008) Glucose Metabolism in Lymphocytes Is a Regulated Process with Significant Effects on Immune Cell Function and Survival. Journal of Leukocyte Biology, 84, 949-957. https://doi.org/10.1189/jlb.0108024

42. Black, C.T., Hennessey, P.J. and Andrassy, R.J. (1990) Short-Term Hyperglycemia Depresses Immunity through Nonenzymatic Glycosylation of Circulating Immunoglobulin. Journal of Trauma, 30, 830-832. https://doi.org/10.1097/00005373-199007000-00012

43. Taylor, J.H. and Beilmam, G.J. (2005) Hyperglycemia in the Intensive Care Unit: No Longer just a Marker of Illness Severity. Surgery Infection, 6, 233-245. https://doi.org/10.1089/sur.2005.6.233

44. Dong, W.H., Hou, X.X., Zhang, P.L., Zhou, Y.L., Yang, Y.P. and Xue, X.P. (1990) A Study on Population Quantity Composition and Reproduction of Striped Hairy-Footed Hamster. Acta Theriologica Sinica, 10, 221-226.

45. Dong, W.H., Hou, X.X., Zhou, Y.L., Zhang, Y.X., Lang, B.J. and Xue, X.P. (1998) Studies on Population Dynamics and Prediction of Phodopus sungorus. Acta Agrestia Sinica, 6, 207-211.

46. Yellon, S.M., Teasley, L.A., Fagoaga, O.R., Nguyen, H.C., Truong, H.N. and Nehlsen-Cannarella, L. (1999) Role of Photoperiod and the Pineal Gland in T Cell-Dependent Humoral Immune Reactivity in the Siberian Hamster. Journal of Pineal Research, 27, 243-248. https://doi.org/10.1111/j.1600-079X.1999.tb00622.x

47. Demas, G.E. (2002) Splenic Denervation Blocks Leptin Induced Enhancement of Humoral Immunity in Siberian Hamsters (Phodopus sungorus). Neuroendocrinology, 76, 178-184. https://doi.org/10.1159/000064527

48. Bartness, T.J. and Goldman, B.D. (1989) Mammalian Pineal Melatonin: A Clock for All Seasons. Experientia, 45, 939-945. https://doi.org/10.1007/BF01953051

49. Zysling, D.A., Garst, A.D. and Demas, G.E. (2009) Photoperiod and Food Restriction Differentially Affect Reproductive and Immune Responses in Siberian Hamsters Phodopus sungorus. Functional Ecology, 2-10.

50. Demas, G.E., Drazen, D.L. and Nelson, R.J. (2003) Reductions in Total Body Fat Decrease Humoral Immunity. Proceedings of the Royal Society B, 270, 905-911. https://doi.org/10.1098/rspb.2003.2341

51. Xu, D.L., Hu, X.K. and Tian, Y.F. (2017) Effect of Temperature and Food Restriction on Immune Function in Striped Hamsters (Cricetulus barabensis). Journal of Experimental Biology, 220, 2187-2195. https://doi.org/10.1242/jeb.153601

52. Xu, D.L. and Hu, X.K. (2017) Photoperiod and Temperature Differently Affect Immune Function in Striped Hamsters (Cricetulus barabensis). Comparative Biochemistry and Physiology, Part A, 204, 211-218.

53. Matarese, G. (2000) Leptin and the Immune System: How Nutritional Status Influences the Immune Response. European Cytokine Network, 11, 7-14.

54. Lord, G.M., Matarese, G., Howard, J.K., Baker, R.J., Bloom, S.R. and Lechler, R.I. (1998) Leptin Modulates the T-Cell Immune Response and Reverses Starvation-Induced Immunosuppression. Nature, 394, 897-901. https://doi.org/10.1038/29795

55. Flier, J.S. (1998) Lowered Leptin Slims Immune Response. Nature Medicine, 4, 1124-1125. https://doi.org/10.1038/2619

56. Chandra, R.K. and Sarchielli, P. (1996) Body Size and Immune Responses. Nutrition Research, 16, 1813-1819. 
Submit or recommend next manuscript to SCIRP and we will provide best service for you:

Accepting pre-submission inquiries through Email, Facebook, LinkedIn, Twitter, etc.

A wide selection of journals (inclusive of 9 subjects, more than 200 journals)

Providing 24-hour high-quality service

User-friendly online submission system

Fair and swift peer-review system

Efficient typesetting and proofreading procedure

Display of the result of downloads and visits, as well as the number of cited articles

Maximum dissemination of your research work

Submit your manuscript at: http://papersubmission.scirp.org/

Or contact ns@scirp.org 